\title{
20 Moral Demands and Ethical Theory: The Case of Consequentialism
}

\author{
Attila Tanyi
}

\section{Introduction}

Morality is demanding; this is a platitude. It is thus no surprise when we find that moral theories too, when we look into what they require, turn out to be demanding. However, there is one leading moral theory - consequentialismwhich is confronted to by a demandingness problem. The demands the theory makes on us are so great (or so the argument runs) that consequentialism must be rejected. It simply requires too much of us.

This objection gives rise to a number of pressing questions. Is it right to claim that consequentialism makes excessive demands? Is there a limit on how demanding morality can be? Why single out consequentialism? Is it the only moral theory that makes unacceptably high demands? If the demandingness problem is real, what is the consequentialist's best response? This chapter sets out to answer these questions (or at least point to how they could be answered).

The chapter has the following structure. I will first present the objection (section II), then explain how it differs from other objections (section III) and why it targets consequentialism in particular (section IV). We will see that it not at all easy to explain why the trouble with consequentialism is on account of its demandingness only. After this, I will present the objection in a more formal way that helps me to introduce the different ways of responding to it (section V). In the remainder of the chapter, I will discuss three (relatively) underexplored responses: (1) a response that introduces a new, multidimensional version of consequentialism (section VI); (2) a response that focuses on the role of institutions in lowering demands on individuals by introducing an institutional division of labor (section VII); and (3) response that changes the focus to reasons and their connection to consequentialist demands (section VIII). I then end with a brief summary and make some concluding remarks (section IX). 


\section{Consequentialism and Demandingness}

Start with the targeted theory. ${ }^{1}$ Consequentialism, in its most general sense, is the view that normative properties depend only on consequences. This general approach can be applied at different levels to different normative properties of different kinds of things, but the most prominent example is consequentialism about the moral rightness of acts. This (moral) consequentialism holds that whether an act is morally right depends only on the consequences of that act or of something related to that act, such as the motive behind the act or a general rule requiring acts of the same kind, as judged from an impersonal perspective.

The paradigm case of moral consequentialism is utilitarianism, whose classic proponents were Jeremy Bentham, John Stuart Mill, and Henry Sidgwick. These classical utilitarians were all act-consequentialist: They held that whether an act is morally right or wrong depends only on its consequences (as opposed to the circumstances or the intrinsic nature of the act or anything that happens before the act or anything that relates to the act). They were utilitarians because they advocated consequentialism with a welfarist theory of value, that is, a theory that focuses on human welfare, well-being, or happiness as the relevant consequence. And since they understood happiness in terms of the balance of the amount of pleasure over pain, they were also hedonists. The demandingness objection has originally targeted these classical utilitarians, but can be employed against any form of act-consequentialism. ${ }^{2}$

What exactly does the objection say? Discussions of the objection normally begin with short stories like the following two: ${ }^{3}$

The Envelope. On your desk is an envelope addressed to a reputable charity seeking donations to save the lives of victims of a famine or other natural disaster. Utilitarianism says you should give all your money to this charity, as each dollar will produce more happiness in their hands than you could possibly produce by spending it in any other way.

Your Money and Charity. You are wondering whether to spend a pound on chocolate for yourself or to give it to a certain charity. You know that this charity is unusually effective and that even a small contribution can help them save a child from some crippling and painful illness. Since you obviously do more good by saving a child from illness than by eating a piece of chocolate, you ought to give the pound to charity. However, if you repeat this utilitarian reasoning every time you have a pound to spare, you will end up very poor indeed.

The first story, The Envelope, gives us the traditional version of the objection with one large consequentialist demand countering whatever else the agent 
might be planning to do. The second story, Your Money and Charity, is designed to show how small but iterated demands can add up to altogether excessive demands. ${ }^{4}$ In either the case, the message is the same: the demands of consequentialism are excessive and, therefore, objectionable. ${ }^{5}$

Let us now have a closer look at the structure of the objection. It is built upon two pillars: (1), that consequentialism is excessively demanding, and (2) that an adequate morality cannot be excessively demanding. Consequentialism requires the agent to promote the good (consequences) until the point where further efforts would burden the agent as much as they would benefit others. However, the situation that determines what would be best overall is far from ideal: today's world involves, for example, significant levels of poverty that prevailing levels of charitable donations are insufficient to eradicate. ${ }^{6}$ Given that acting to alleviate poverty is likely to have, in sum, more positive consequences than pursuing individual goals and projects, it seems unavoidable that, if one fully accepts consequentialism, one must devote most of one's resources to humanitarian work. Both The Envelope and Your Money and Charity make the same point in their own, more particular way. At the same time, so the objection assumes, most people have a firmly held judgment that this cannot be right, that people should not be required to sacrifice their lives for morality. This is the second pillar of the objection. Its function is to ground a constraint on admissible moral theories requiring them to avoid excessive demands. If they do not, the conclusion follows that these theories should not be allowed to guide people's conduct.

\section{Demandingness and Other Objections}

The demandingness objection makes a simple case against consequentialism: Since the consequentialist agent is required to maximize the overall balance of good consequences, this is excessively demanding (in our present circumstances), hence objectionable (because one should be given the opportunity to have a life outside morality). To get a clearer grasp of the objection, it is useful to contrast it with other objections to consequentialism that are often bundled together with it. This will ultimately also contribute to our understanding of why consequentialism is singled out by the objection as its sole target.

Here is a famous case from Bernard Williams (1973a: 98-9):

Jim and the Indians. "Jim finds himself in the central square of a small South American town. Tied up against the wall are a row of twenty Indians, most terrified, a few defiant, in front of them several armed men in uniform. A heavy man in a sweat-stained khaki shirt turns out to be the captain in charge and, after a good deal of questioning of Jim which establishes that he got there by accident while on a botanical expedition, 
explains that the Indians are a random group of the inhabitants who, after recent acts of protest against the government, are just about to be killed to remind other possible protestors of the advantages of not protesting. However, since Jim is an honoured visitor from another land, the captain is happy to offer him a guest's privilege of killing one of the Indians himself. If Jim accepts, then as a special mark of the occasion, the other Indians will be let off. Of course, if Jim refuses, then there is no special occasion, and Pedro here will do what he was about to do when Jim arrived, and kill them all. Jim, with some desperate recollection of schoolboy fiction, wonders whether if he got hold of a gun, he could hold the captain, Pedro and the rest of the soldiers to threat, but it is quite clear from the set-up that nothing of that kind is going to work: any attempt at that sort of thing will mean that all the Indians will be killed, and himself. The men against the wall, and the other villagers, understand the situation, and are obviously begging him to accept. What should he do?"

In sum, Jim gets to choose between two actions: (i) not killing anyone himself, yet thereby causing the death of twenty villagers. Or (ii) killing one of the villagers himself, thereby ensuring that the others go free. Williams argues that a utilitarian cannot avoid that conclusion that (i) is the morally required course of action: Jim should kill one villager.

However, this conclusion can be found troubling for three reasons; Williams himself mentions two. One, the utilitarian reasoning makes it clear that it does not matter how certain consequences are produced: Whether Jim kills one villager, or Pedro, as a result of Jim's refusal, kills all twenty, matters only to the extent that in the latter case the consequences are worse. Utilitarianism is insensitive to the distinction between doing and allowing, which in this particular case translates into the distinction between killing someone and allowing them to die (by failing to prevent Pedro's act). The result is what Williams (1973a: 95) calls negative responsibility: "that if I am ever responsible for anything, then I must be just as responsible for things that I allow or fail to prevent, as I am for things that I myself, in the more everyday restricted sense, bring about."

However, Williams argues that the fact that utilitarians cannot escape endorsing negative responsibility is a flaw of the utilitarian theory. According to Williams, it matters morally whether you cause an outcome actively (i.e., by producing a certain course of actions) or passively (by refraining to act in a certain way and thus allowing it to happen). It also matters if the chain of causal events that produces an outcome contains someone else's act and decision or not, that is, if an outcome includes someone else's doing or solely my own doing. In short, "each of us is specially responsible for what he does, rather than for what other people do" (ibid.: 99). Utilitarianism does not respect this important moral insight and therefore it cannot be the correct moral theory. 
So this is one problem with consequentialism. But Williams does not stop here. He argues that endorsing negative responsibility leads to alienation from one's own life projects and, ultimately, to the disintegration of the self (ibid.: $116-17):^{7}$

The point is that [the agent] is identified with his actions as flowing from projects or attitudes which ... he takes seriously at the deepest level, as what his life is about ... It is absurd to demand of such a man, when the sums come in from the utility network which the projects of others have in part determined, that he should just step aside from his own project and decision and acknowledge the decision which utilitarian calculation requires. It is to alienate him in a real sense from his actions and the source of his action in his own convictions. It is to make him into a channel between the input of everyone's projects, including his own, and an output of optimific decision; but this is to neglect the extent to which his actions and his decisions have to be seen as the actions and decisions which flow from the projects and attitudes with which he is most closely identified. It is thus, in the most literal sense, an attack on his integrity.

Negative responsibility arises from consequentialism's commitment that only consequences matter, not how and by whom they are produced: what count are the (valuable) states of affairs produced and nothing else. But this means that a utilitarian who is committed to thinking in this way is also committed to look at his or her own projects in the same way: not as in any particular sense his or her own, but as only one among many others that matter only to the extent that when satisfied, pursued, accomplished, and so on, they produce valuable states of affairs. However, Williams (ibid.: 116) argues, this is not how we relate to the projects we identify with and committed to. He famously asks: " $[\mathrm{H}]$ ow can a man, as a utilitarian agent, come to regard as one satisfaction among others, and a dispensable one, a project or attitude round which he has built his life, just because someone else's projects have so structured the causal scene that this is how the utilitarian sum comes out?"

Take Jim and the Indians. Jim is a harmless academic who does not want to kill: this, we can assume, is a central commitment in his life. He lives and sees this project, as it were, from the inside-from a first-person, partial point of view. However, utilitarianism is another project and maybe it is even another project of his: it is, moreover, a higher-order project that feeds on these lowerorder projects since it is the satisfaction of these projects that produces the relevant valuable consequences. Now, this higher-order project requires Jim to look at his lower-order project of not killing, as it were, from the outside-from a third-person, impartial point of view. ${ }^{8}$ And from this viewpoint, his project loses all its peculiar, personal meaning and becomes only one project among 
many other projects of many other people. It is just another project with a label on it - "permitted" or "not permitted" - and nothing more, depending on how "the utilitarian sum comes out." But this is a project that, at least in part, defines Jim as he is; it is not merely a labeled item for him. ${ }^{9}$ Hence utilitarianism, when it requires him to forget all about this, also alienates him from these projects and destroys the unity and shape of the particular life-his life - that is built around them; in short, it destroys his integrity. ${ }^{10}$

What underlies the first two problems with consequentialism is the same feature of the theory: its exclusive reliance on consequences. It is only these valuable states of affairs that matter, not how and by whom they are produced: if the right sum comes out, nothing else matters. In particular, there is no place for respecting particular persons' particular projects or welfare: people appear to be mere carriers of the good, elements in the causal chain who are needed only to produce valuable consequences. This leads the theory not to respect basic moral distinctions (how consequences are produced and who causes them) and to produce alienation and loss of integrity (given how people relate to their commitments and projects they identify with). However, as John Rawls (1971: 26-7) has famously argued, this feature also causes consequentialism to fail at the most basic metaphysical level, because it does not take seriously the separateness of persons:

The striking feature of the utilitarian view of justice is that it does not matter, except indirectly, how this sum of satisfaction is distributed among individuals any more than it matters, except indirectly, how one man distributes his satisfaction over time. The correct distribution in either case is that which yields the maximum fulfillment ... Utilitarianism does not take seriously the distinction between persons.

The three objections paint a clear alternative picture to consequentialism. Each of us has a particular, separate life to live, a life that has a particular shape and unity, as defined by the projects and commitments we have, around which our lives are organized. Hence, it matters that we do something or someone else does or that it was our project that was thrown out in order to produce the best overall consequences.

However, while this is true, it is also clear that these objections to consequentialism are different from the demandingness objection. First, they target different things. They are not designed to question the excessive demands of consequentialism, but to object to its picture of the self (both metaphysical and motivational) and its disrespect for certain important moral distinctions. Second, the three alternative objections do not necessarily connect to excessive demands. This is clearly so with the integrity objection: any theory, whether demanding or not, violates agential integrity if it does not respect the way 
agents relate to their projects and commitments. As for the other two objections, they play a part in creating excessive demands, but they certainly are not the only ingredients: maximization (of valuable consequences) is another and the particular theory of value employed (whether it concerns human or sentient welfare, for instance) is a third, and there can be others. Finally, third, one can defend the distinction between doing and allowing, argue against the separateness of persons, and find a way around the integrity objection, without doing anything about the demandingness of consequentialism. ${ }^{11}$

\section{Why (Only) Consequentialism?}

Yet, it might be the case that the three objections are vital for understanding why the demandingness objection is typically considered as exclusively targeting consequentialism. Recall our original question: why is only consequentialism targeted in this way? It seems that other moral theories are comparably demanding. Take two popular alternatives to consequentialism. Deontology, typically associated with the name of the German philosopher Immanuel Kant, holds that there are certain things that simply cannot be done to people: these considerations, often called "rights," function as absolute prohibitions on our actions. Another popular theory, virtue ethics, argues that the right thing to do is what the virtuous person would do, that is, the person who possesses certain character traits and dispositions ("virtues" such as honesty, courage, justice, and so on) to the maximum degree. However, as is often pointed out, Kantian prohibitions on deception can be excessively demanding in certain situations when, for instance, the only way to save lives is by lying about the whereabouts of people; emulating ideally virtuous characters (think of Mother Theresa, Gandhi, or Jesus) is arguably excessively demanding, yet, this is what virtue theory asks us to do. And these are only two examples of a non-consequentialist moral theory requiring us to give up our personal plans, projects, commitments for morality's sake. So why is only consequentialism singled out as objectionably demanding? Now, one thing that could be said in response is that the three alternative objections point to those aspects of consequentialism that explain why its demandingness is objectionable: because it does not respect the separateness of persons, or because it does not respect agential integrity, or because it does not respect the distinction between doing and allowing (cf. Mulgan 2001: 15-18).

My problem with this suggestion is that it seems to go against the self-standing status of the demandingness objection. If the only problem with the demandingness of consequentialism, that is, the aspect that distinguishes its demands from the similarly excessive demands of other moral theories, is that it runs into one of the objections above, then it is these aspects-no respect for integrity, no respect for separateness, no respect for certain moral distinctions - and 
not the demands per se that are objectionable. In other words, the reason why we reject consequentialism is not its excessive demandingness but something else that these demands only track, connected to, or derived from.

There is a clear parallel here with two influential responses to the demandingness objection. David Sobel (2007) has argued that there is a way to support the objection, but this support presupposes "prior and independent breaks with consequentialism," that is, prior to and independent of issues of demandingness. This break concerns the distinction between the costs a moral theory requires the agent to bear and the costs a moral theory permits to befall on other people as a result of not requiring agents to prevent something happening to these people. ${ }^{12}$ The demandingness objection, he argues, only focuses on costs a moral theory requires to bear, and totally disregards the costs a moral theory permits; this is why it says that consequentialism is objectionably demanding. However, this distinction and the resulting choice presupposes that we already know something about "the true shape of morality" before we employ the objection. That is, when we are concerned with the objection what we are concerned with is not excessive demands, but something else that our complaints only track, namely the distinction between the two kinds of costs.

Liam Murphy (2000) bases his cooperative consequentialism on an analogous diagnosis of the demandingness objection. Unlike Sobel, his focus is not on certain moral distinctions but on the fairness of moral demands. His claim is that the problem with consequentialism is not that it demands too much, but that its demands are unfair. Consequentialism is insensitive to the contributions of others, hence it requires one to contribute more if the others contribute less. In other words, it requires the agent to pick up the slack that is produced by the non-compliance of others. This indeed makes the demands of consequentialism excessive but this is not why we object to them: we object to them because they are unfair. So again, although there is an issue with the excessive demands of consequentialism, their excessiveness is not what the issue is; it at best tracks or connected to the real problem: namely, their unfairness.

It is not my aim in this chapter to evaluate these varying analyses and the responses they give rise to, but to point out that, as Murphy nicely puts it, they do not solve the demandingness objection but dissolve it: understood along these lines-be that integrity, separateness, fairness, or else-the demandingness objection ceases to be an objection to consequentialism on account of its demandingness. What else can we say to explain why consequentialism is objectionable solely on account of its demandingness and other, similarly demanding moral theories are not? I see three strategies. One is to refuse to answer the question. We can accept that consequentialism is not alone in being excessively demanding and hold that either all theories that make high demands are objectionable, or none are. ${ }^{13}$ The trouble with this way of reasoning is that it is widely accepted that there is something about consequentialism 
that makes it objectionably demanding that is not present in other, similarly demanding moral theories. The best would be to respect this common intuition instead of disregarding it. ${ }^{14}$

So let us look for alternative explanations. One is offered by the notion of supererogation. The idea is that consequentialism, unlike non-consequentialist theories, has no place for acts that go beyond the call of duty: acts that are morally admirable, hence morally permitted, but not demanded, that is, morally required. Non-consequentialists can accept the existence of such actions since they do not require the agent to do what is best impersonally. Kantian deontology, for instance, can hold that within the bounds of certain prohibitions, actions that produce the best consequences are permitted but not required. This is why consequentialism is objectionably demanding while other theories are not: it does not leave room for these supererogatory options. The trouble with this explanation is that many question the coherence of supererogation. It appears to be paradoxical if one, reasonably, assumes that one has more moral reason to do what is better overall. Since this is the case with supererogatory acts, then the question arises: how can one be morally permitted to do something when one has more moral reason to do something else? There may be answers to this question, but it is also important, in the present context anyway, that the resolution of the paradox is such that it keeps the demandingness problematic in place.

Assuming the paradox can be resolved in the "proper" way, supererogation could offer us a way to explain the special demandingness of consequentialism. ${ }^{15}$ A second explanation comes from Doug Portmore (2011: 4). He focuses on what I would call consequentialism's sensitivity to incremental changes in demands. He makes the point like this: "Utilitarianism implies that agents should sacrifice, not only their disposable income, but even their own lives and the lives of those whom they love most whenever doing so will produce the most aggregate utility, and, thus, even when the net gain would be as small as one utile" (ibid., referring to Hooker 2000: 151-2). On this explanation then, the reason why we find consequentialism objectionably demanding but other similarly demanding moral theories not, is that, unlike those other theories, consequentialism gives rise to high demands while being too sensitive to incremental changes in the overall balance of good consequences. This may well appear to be objectionably demanding, as Portmore's quoted example illustrates.

\section{Two Readings and Responses to One}

The overall message of the preceding discussion is that it is not easy to find an explanation of the demandingness objection that keeps its self-standing status as well as the form in which it is normally offered: as an objection to 
consequentialism and consequentialism alone. Yet, as I tried to demonstrate in the previous section, there are ways of explaining why consequentialism is the exclusive target of the objection. From this point on, therefore, I assume that the objection is in good shape. How can one respond to it? In this short section, I would like to go through the main responsive strategies (although not all of them, as I explain below). To do this, the best is to start afresh; having reached half way in the chapter, this is a good idea anyway. Take the objection again. What does it say?

We should separate two readings of the objection. They are distinguished by how one spells out the idea that excessive consequentialist demands are objectionable (Portmore 2011: 26 referring to Dorsey 2012). Consequentialism can be understood as wrongfully demanding if it requires agents to make sacrifices that they are not, in fact, morally required to make. Alternatively, consequentialism can be understood as unreasonably demanding if it requires agents to make sacrifices that they do not have decisive reason to make. ${ }^{16}$ In this and the coming two sections I focus on the first reading, which has a more influential historical pedigree.

For a (new) start then, let us pull the threads together. The demandingness objection starts from the excessive nature of consequentialist demands. It claims that these demands, therefore, are objectionable. We now know what this stands for: consequentialist demands are objectionable because they are not demands that we are in fact morally required to make. In short, consequentialism is wrongfully demanding. There is still the question why this is so, given that other moral theories make similarly excessive demands with a similarly detrimental effect on our personal, non-moral lives. Why is consequentialism the only target of the objection? This is a difficult question to answer but in the previous section I provided two-admittedly, provisionalanswers: excessive consequentialist demands do not leave room for supererogatory actions, or, they are absurdly insensitive to incremental changes in the overall balance of valuable consequences. This is what makes them not only excessive, but objectionable, in the moral sense outlined here.

So this is where we stand. How can we respond to the objection understood in this way? We can put the objection somewhat more formally as making the following argument:

(1) Consequentialism makes demand D;

(2) Demand D is not a wrongful demand;

Therefore,

(3) Consequentialism is wrongfully demanding;

(4) If a moral theory is wrongfully demanding, then we have reason to reject it; 
Therefore,

(5) We have reason to reject consequentialism.

This more detailed structure gives us guidance in devising the most effective response strategy. Of these, the following two responses figure most frequently in the literature. ${ }^{17}$ The strategy of denial rejects premise (1) either because it holds that the premise rests on false empirical facts or because it aims to restructure consequentialism in such a way that it no longer makes the demand. ${ }^{18}$ Taking an entirely different stance, the strategy of extremism does not deny that consequentialism makes high demands; what it denies is that these high demands are objectionable because not right: that is, it rejects premise (2) ${ }^{19}$ It does this by undermining or discrediting the intuition that the premise uses as support. Thus, it is argued that this intuition rests on lack of information, lack of clear thinking, lack of imaginative empathy or on some psychological "failure," or that it tracks something entirely different from issues of excessive demands, or that its (typically, evolutionary) origins are such that we have no reason to take it seriously. ${ }^{20}$

Much has been written about these attempts but in this chapter I will not aim to rehearse the points already made about well-known approaches. Instead, in the following two sections, I will focus on two ideas that have been left relatively unexplored by others. They can both be categorized as versions of the strategy of denial. I am not convinced about the success of either and will therefore approach them with caution: I will try to sketch how the answer to the demandingness objection would go and make some critical points along the way. First I will discuss a new version of consequentialism, called multidimensional consequentialism that was recently developed by Martin Peterson. Then I will move on to the role institutions may play in reducing the demands of consequentialism on individuals. In the last substantial section of this chapter I will turn to the second reading of the objection mentioned above in order to sketch possible responses and their potential problems.

\section{Multidimensional Consequentialism and Demandingness}

In his recent book, Martin Peterson (2013) puts forward a new version of consequentialism that he dubs "Multidimensional Consequentialism" (MDC). ${ }^{21}$ Peterson claims that his theory is in significant respects superior to other consequentialist theories: it is intuitively more appealing and it manages to avoid many of the influential objections to consequentialism, among them our particular interest, the demandingness objection.

The best place to start our investigation is Peterson's definitions of MDC (3f.):

Let the set of $C^{*}$-aspects be the set of all properties that can affect an act's deontic status according to consequentialist theories, e.g., the wellbeing 
produced by the act, or its degree of equality, and so on. The key distinction researched in this book can then be stated as follows:

One-dimensional consequentialism ${ }_{\text {def }}$ the view that an act's deontic status can be characterised by a one-place function of some $\mathrm{C}^{*}$-aspect.

Multidimensional consequentialism ${ }_{\text {def }}$ the view that an act's deontic status can only be characterised by a function of several $C^{*}$-aspects.

Several elements of these definitions require explanation and/or further elaboration. First, in line with how I understand the theory, consequentialism on Peterson's reading is the view that "the deontic status of an act depends only on consequences" (1). Peterson dubs this principle $C^{*}$. Moral aspects are those properties that directly influence the deontic status of an act, where "influence" is understood in terms of functions: "An aspect, $a$, directly influences the deontic status, $d$, of an act if and only if $d$ is a function of $a^{\prime \prime}$ (3). ${ }^{22}$ Putting these three-principle $C^{*}$, moral aspects, influence as function-together, we get Peterson's definitions above. ${ }^{23}$

Second, moral aspects are not the same as moral dimensions. "A dimension," Peterson explains, "can be conceived of as the conceptual space in which an aspect can be altered" (4). ${ }^{24}$ This also means, as Peterson subsequently admits, that a consequentialist theory that identifies several moral aspects as affecting the deontic status of an act need not be properly speaking multidimensional because all these aspects might belong to the same dimension. However, for reasons of convenience and because his particular version will identify moral aspects that belong to different dimensions, Peterson keeps the label "multidimensional' throughout the book and I follow him on this.

Finally, third, moral aspects that determine deontic status must be irreducible. This is in fact the defining thesis of MDC and follows from the definition given above. Peterson labels the thesis $\mathrm{C} 1$. One-dimensional consequentialists must reject $\mathrm{C} 1$; multidimensional consequentialists must endorse it. However, Peterson goes on to claim that "in order to formulate a normatively plausible multidimensional theory, which fits well with our considered intuitions, two further non-definitional claims need to be added. Both these claims raise substantial moral issues and are logically independent of C1" (8).

The first additional claim is C2: "The binary relation 'at least as good consequences as' is not a complete ordering" (8). The idea behind this thesis is that different moral aspects are either incomparable or on a par - "that it is impossible to establish a precise exchange rate between all relevant aspects"25 (9). The last defining thesis of Peterson's version of MDC is given by C3: "Moral rightness and wrongness are non-binary entities, meaning that moral rightness and wrongness vary in degrees" (9). Peterson's idea is simple: not all acts are either entirely right or wrong; some acts fall within this spectrum being in part right and in part wrong. To sum up, Peterson cashes out the deontic 
status - the all-things-considered moral rightness or wrongness - of an act as a function of separate, irreducible, and incomparable (on a par) moral aspects (dimensions). He explicitly mentions three such aspects-well-being (persons), equality, and risk - but this is not intended as a comprehensive list.

There is, of course, a lot to say about the plausibility of Peterson's theory but this is beyond the scope of this chapter. ${ }^{26}$ We should instead concentrate on how MDC responds to the demandingness objection. Peterson claims that MDC has the resources to defuse the objection because it can hold that donating is both right and wrong at the same time (47-8). The idea, as Peterson explains (70), is that those who donate excessively damage their own as well as their loved ones' well-being. That this is so is hard to doubt: the demandingness objection builds just on this observation (recall my introduction in section II). Since, according to Peterson, persons' well-being count separately, this influences the calculation of all-things-considered rightness by making excessive donation less right and more wrong. Why does each person's well-being count separately? Because, as I indicated above, "person" is a separate moral aspect in MDC: Unlike customary consequentialist calculations that, as we saw, do not take account of whose well-being is affected, MDC considers each person's well-being separately, as playing a separate part in determining the deontic status of an act. This helps the theory to avoid the separateness of persons objection as well as, or so Peterson claims, the demandingness objection.

I find this new take on consequentialism intriguing and its response to the demandingness objection appealing. Yet, I would like to raise one critical point that offers at least something to ponder upon for an advocate of MDC. Start with the following general problem. One purpose of (deontic) allthings-considered judgments-judgments one arrives at after having taken into consideration everything that pertains to the rightness or wrongness of the given action-is the provision of action-guidance. However, all-thingsconsidered judgments are not action-guiding in a satisfactory way if they do not single out at least one action as the thing to do-and this is exactly what MDC doesn't do. (Imagine the following conversation: "What ought I to do?" - "Well, there is nothing it would be entirely right for you to do. To some extent..." - "What?!") This seems to spell trouble for the theory.

Now, Peterson could reply that on his theory the thing to do is the action that is most right in the given circumstances. ${ }^{27}$ However, if the thing to do on MDC is the act that is most right in the given situation, it is far from clear that Peterson can indeed disarm the demandingness objection. For, if the thing to do is the act with the highest deontic score ("most right"), it is well possible that, given the world as it is, consequentialism will still come out as excessively demanding. In other words, it is not enough if Peterson can show that excessive donation on MDC is not entirely right; he must also show that the ranking of alternative acts is such that excessive donation does not come out on top. ${ }^{28}$ Although this is no knockdown objection to MDC, it shows that lots 
of details must be filled in before we get a truly convincing response to the demandingness objection. MDC doesn't, in other words, just by construction, accomplish this.

Peterson could try to get around this problem by holding that the thing to do is not what is most right to do in the given situation but what is sufficiently right to do. However, besides the fact that this raises the question of where we draw the line (what is sufficiently right?), we also end up with the mirror of the debate about satisficing consequentialism (and/or sufficientarianism in theories of distributive justice). ${ }^{29}$ Another possible way-out for Peterson would be to adopt agent-relative theories of value-or maybe a person-relative dimension of value. Again, however, this would leave us with the mirror version of an ongoing debate. ${ }^{30}$ In general, arguments based on satisficing, agent-relative value, and so on, would be disappointing in the present context, for the hope was for MDC to escape the demandingness objection in virtue of multidimensionality and not in some other way.

\section{Institutions and Demands}

The core idea of this response, well known from the literature on John Rawls' theory of justice, is to direct attention to the ability of institutions to reduce moral demands on individuals. This is possible because a division of labor is justifiable: the demanding moral principles regulate institutions, whereas individuals "only" have the duty to set up and maintain these institutions. However, in order to get off the ground, this "institutional approach" has to tackle two basic challenges. First, Liam Murphy (1998) has argued that demandingness considerations will not give us what he calls dualism: the idea that different principles apply to institutions and to individuals. And, the thought is, we need dualism to substantiate the present response to the demandingness objection. Second, consequentialism, unlike, for instance, the Rawlsian system, appears to be a monist theory in Murphy's sense: the same principle (of beneficence) applies to individuals as to institutions. Hence the dualist idea that is taken to underlie the present response to the objection may not be justifiable in the case of consequentialism, whether or not the demandingness objection can lead us to dualism.

I believe that both objections can be answered. There is, first, the question whether we indeed need to appeal to dualism in order to respond to the demandingness objection. As Murphy's own discussion demonstrates (ibid.: 262-3), this need not be so: a monist theory can accommodate division of labor between institutions and individuals without making use of dualism itself. This is because it simply makes good sense, from within the monist theory, to leave the thrust of the burden of justice (Murphy's primary interest) to institutions allowing people to live their lives. Second, one can keep dualism as the 
answer to the demandingness objection without going along with the stronger idea that it is the objection itself that necessitates our endorsement of dualism. Rawls and others provide good reasons in favor of dualism - I mention some of these below - that are not discussed by Murphy. Once these reasons are on the table, one can hold that we should endorse dualism for these reasons and this will still give us a response to the objection as a (perhaps unintended) side effect of the division of labor that dualism secures for us.

There is, moreover, and despite Murphy's point above, good reason to endorse dualism and not simply to rely on monism's ability to accommodate the idea of division of labor. In the (Rawlsian sense) non-ideal circumstances we live in, a monist theory poses too much risk for those who want to tackle the demandingness objection. ${ }^{31}$ For it is likely to be the case that in many circumstances, think of global challenges for instance, we cannot rely on institutions to do the bulk of the work for us (either because they do not exist or because they are not efficient enough). In such cases monism requires individual contribution that might well turn out to be excessively demanding. This, however, makes the second problem above even more pressing. Rawls and others following him use consequentialism as the prime example of a comprehensive, monist theory: the principle of beneficence should apply both to institutional and to individual conduct. How can we deny this? The answer is that we do not have to deny it insofar as it is properly understood. Let me explain.

The key move here is to introduce a distinction discussed at length by Samuel Scheffler $(2005,2006)$. There are two versions of the idea of division of labor in Rawls's work. There is, first, a division of moral labor that urges us to have separate moral principles for institutions and individuals on the ground that they promote different moral values. Since the relevant moral values in the case of individuals also have to do with partial concerns - such as special relationships or self-interest-this is indeed a form of division of labor that consequentialism cannot make use of; on this reading consequentialism must be a monist theory.

The institutional division of labor, on the other hand, relies on the idea that there are two kinds of social rules-one for the design of the basic institutional structure of society and the other for individual conduct. Principles of justice belong to the first kind for several reasons, most prominent among them is the consideration that in maintaining what Rawls calls background justice, epistemological challenges arise that cannot be faced by individuals on their own. It simply takes a lot to figure out in a complex system like a state-governed society what exactly a moral principle, even if it is simple, requires: no individual is capable of gathering the relevant data and carry out the necessary computations and reasoning. Another good reason for the institutional division of labor is the constitutive role institutions play in determining the demands of justice (Miklósi 2008 and Miklós 2013). To mention 
one consideration, fundamental moral principles underdetermine moral requirements; hence, it is not possible to understand what a moral principle demands prior to the operation of institutions. One way this can happen is that moral principles, although give us a set of options to choose from, cannot make the choice themselves: they do not single out a unique set of distributive shares, or rights, or obligations. Institutions, such as the legal system, can however do just this - and until this is done, it is not determined what exactly is the right thing to do.

It seems to me that both considerations can also be applied to the case of consequentialism. Application of the theory clearly faces serious epistemological challenges, nor is the theory different from its main competitors concerning the indeterminacy of its requirements. If this is so, it seems we have found a way for marrying consequentialism and dualism. Moreover, if this claim is sound, it should also suffice to answer Murphy's influential objection to dualism: that it is perverse to require people to establish and maintain just (in this case: consequentialist) institutions, but not require them to personally pursue the aim of justice (when this is the most efficient way to proceed). For, there are good reasons to single out institutions as morally special (in fact, there are more good reasons than what I have-very briefly-presented above) that make a perfectly good case for why individuals shouldn't-because, as far as the reasons above are concerned, couldn't-pursue the aim of justice individually. ${ }^{32}$

Having taken (very provisional) care of these initial problems, we can move on to consider the institutional response to the demandingness objection on its (substantial) merits. There are several issues that need to be discussed (including empirical questions concerning the exact demandingness of the institutional approach) but here I only focus on one that I find particularly interesting: global justice. Arguably, the demandingness objection is most persuasive when we appeal to existing global problems (what justice, peace, or the environment would require on the global scale). However, it might seem that the institutional approach is in trouble here since the relevant institutions, but not the demands are missing; hence, dualism cannot be appealed to in response to the objection in this case. ${ }^{33}$ One reply to this objection is to endorse what is often called the relationalist position in the literature on global justice: that claims of justice are grounded in certain institutional relations among people, such as, to mention another influential Rawlsian thought, the mutually beneficial cooperative relations people often maintain. Hence the response: since these relations do not exist globally, there are also no global moral demands. However, I am not personally inclined to endorse this way of thinking about global justice; besides, and this is more important in the present context, consequentialism is the prime example of a non-relationalist theory, that is, one that does not ground claims of justice in institutional relations among people. ${ }^{34}$ Consequentialists seem to be committed to the thought that we have moral duties in virtue of our 
common humanity, for example, the fact, that we all can feel pain and pleasure, or be well-off or badly off in some other way.

With the relationist approach out of the way, we need to find the institutions that can be used as instruments to carry out (and in part constitute) what consequentialism requires on the global level. Without this we cannot make our dualist approach work in practice. Can we find the relevant institutions? There are two ways to proceed. One is to point to already existing institutions on the global level; this is what relationalist advocates of global justice do and we can borrow from them at this point. ${ }^{35}$ Here one can cite such examples as the World Trade Organization (WTO), the International Monetary Fund (IMF), or the World Bank but there is a lot of empirical research done in this field that we cannot do justice here. ${ }^{36}$ The point is that there are already several institutions that can be used for the purposes of fulfilling consequentialist requirements. Naturally, a lot more can be done to improve these institutions and it is a largely empirical matter how this will look like and what it will require (and how demanding this will be).

Another way to go about responding is to make a radical break with what we can consider to be the status quo: why not build a global state instead of relying on already existing but rather constrained institutions? This is what Torbjörn Tännsjö (2008) suggests that we should do. He argues that the three major global problems-lack of world peace, environmental problems, and problems of justice - can only be tackled by a world state. Moreover, he adds, we have a unique window of opportunity to build such a state: the fact that we have only one superpower in existence, namely, the United States. Tännsjö then goes on to master empirical as well as theoretical support for these claims, arguments that I cannot do justice here. However, the message is clear. Global moral demands are real and cannot be evaded. Moreover, we either already have the means for tackling them, or we can develop these means-if needed, in the form of a world state.

To sum up, the institutional approach to the demandingness objection is a promising but certainly insufficiently worked out way to respond to the challenge. The problems are both theoretical and empirical in nature, as I have attempted to demonstrate above; yet, I believe it is worth the effort to work out this approach in detail to see where it takes us and what we can achieve with it.

\section{Consequentialist Reasons and Demandingness}

We are nearing the end of a long journey. There is one response left to discuss but to do this, I need to return to the second reading of the objection in section $\mathrm{V}$ and say a bit more about how it unfolds. Recall, on the second reading the objection claims that consequentialism is unreasonably demanding: it 
requires us to do things that we do not have decisive reason to do. We can formalize the argument in the following way:

(1) Consequentialism makes demand D;

(2) Demand D is unreasonable;

Therefore,

(3) Consequentialism is unreasonably demanding;

(4) If a moral theory is unreasonably demanding, then we have reason to reject it;

Therefore,

(5) We have reason to reject consequentialism.

Unlike the analogous reasoning of the first reading, this argument requires further elaboration. Premise (2) is again supported by an intuition that we supposedly share. It is that consequentialist reasons are not the only reasons around and at least some of the alternative reasons are stronger than consequentialist reasons. Portmore (2011: 32) identifies two such classes of reasons:

(1) reasons that have nothing to do with promoting the good, such as the reason one has to refrain from violating someone's autonomy even when doing so is a means to promoting the good, and (2) reasons that stem from the special relations that we bear to ourselves and our loved ones, such as the reason one has to promote the good by saving one's own loved one as opposed to by helping some stranger save her loved one.

Some of these reasons are moral (those rooted in our respect for others' autonomy or those grounded in special obligations), others are non-moral (those grounded in our self-interest), but their common feature is that consequentialism, as understood here, cannot accommodate them: they have nothing to do with the maximization of impersonal goodness.

The other critical point of the argument is premise (4). Unlike the analogous premise of the first reading, the truth of this premise is not obvious. It is based on the thesis that what morality requires us to do must also be rationally authoritative: it must be backed by decisive reasons. Moral rationalism, as Portmore (ibid.: 28) calls the thesis, brings together the moral and the rational and has many supporters. They understand moral rationalism as a constraint on moral theories: if a moral theory turns out to make demands on us that we are not rationally required to fulfill, it is not a defensible moral theory. Consequentialism is a case at hand due to the existence of (sometimes) stronger non-consequentialist reasons. ${ }^{37}$ 
Notice, moreover, that this account of why we should reject consequentialism could give us a third explanation why the theory is the sole target of the demandingness objection: unlike other moral theories, consequentialism does not respect the existence of non-consequentialist reasons. This is up for discussion, though (do other moral theories indeed respect all these reasons?); but even if this claim turns out to be not the case, the present story can well supplement the two explanations mentioned in section IV. Portmore (ibid.: 4) is clear about this. Consequentialism's sensitivity to incremental changes makes it particularly liable to encounter situations in which non-consequentialist reasons come out as winners: it is hard to accept that a tiny little improvement in the overall goodness of consequences would be enough to rationally justify acting against (some perhaps quite powerful) non-consequentialist reasons.

Let us return to the argument. Counterattacks can be launched at three points. ${ }^{38}$ Premise (1) can again be rejected. This is typically argued by showing that consequentialism can accommodate the kinds of reasons mentioned by Portmore. These attempts have received sufficient attention in the literature and I will not discuss them here. ${ }^{39}$ Next, one can reject premise (2). This can again be done in extremist fashion as in the case of the first reading of the objection. Alternatively, one can carry out empirical research to see if the premise is indeed intuitively supported: if it is indeed part of commonsense morality that these reasons exist and are (sometimes) stronger than consequentialist reasons. However, although I am supportive of such investigations, I certainly would not consider their results decisive. ${ }^{40}$

A third line of response rejects premise (4) by giving up moral rationalism. On the face of it, the attempt is doomed to failure because it marginalizes morality. This is how Hurley (2009: 60) puts the problem:

If we accept that morality, properly understood, provides merely one among other sets of standards, and that this set of standards lacks the distinctive relationship that has been claimed for it to our reasons for acting, then morality is shifted toward the margins of meaningful inquiry into what rational agents such as ourselves have reasons to do. This would be a pyrrhic victory for the consequentialist, vindicating his account of moral standards only by marginalizing the role of such standards in practical reason and deliberation.

I have two problems with Hurley's marginalization charge. One, it is not obviously counterintuitive to hold that consequentialist reasons do not always outweigh our non-consequentialist reasons. Portmore's point about the existence and strength of these alternative reasons suggests this much. So it is far from clear to me why, contra Hurley, consequentialists shouldn't embrace the 
denial of moral rationalism: consequentialist morality is often a marginal affair from a rational viewpoint, why should we deny this? Second, consequentialism, as usually conceived, is a theory of moral standards and not a theory of moral reasons: it is a thesis on what is the right or wrong thing to do, not a claim about what we have reason to do. Hence, we have to augment consequentialism with a suitable theory of practical reasons and then see if this is in line with moral rationalism. However, this is clearly an open-ended project that shouldn't be prematurely given up just because one insists on the truth of moral rationalism. ${ }^{41}$

So far we have operated with a picture of morality and rationality that takes them to be separate realms. One has a theory of moral standards and one has a theory of reasons and then combines them in some way to see if we get to moral rationalism. This way of proceeding seems to equate moral rationalism with what is often called the overridingness thesis: the claim that moral reasons and requirements override non-moral reasons and requirements (Scheffler 1992: 52; Stroud 1998: 171). That the two doctrines amount to the same thing is suggested by the following line of reasoning. Let's first suppose that reasons determine what we are morally required to do. Reasons are not added to or derived from an already existing moral picture, but they are the primary determinants of moral requirements. Let's further suppose that in determining what we are morally required to do, moral reasons play a decisive role: they are the only reasons that count in determining our moral requirements. Finally, let's suppose moral rationalism is true, and hence that what morality requires us to do must also be rationally authoritative. The end result is the overridingness thesis: moral reasons and requirements will invariably outweigh all non-moral reasons and requirements.

But, as Portmore (2011: 38-40) points out, it is a mistake simply to equate moral rationalism with the overridingness thesis. In fact, disambiguating these theses is crucial because it shows us that there is another way for consequentialists to avoid the demandingness objection. Portmore embraces this opportunity. He argues that, contrary to the second claim above, moral as well as non-moral reasons determine what we are morally required to do. Why is this crucial? Because it makes the following strategy possible (ibid.: 41-2):

So although some may be compelled to accept moral rationalism because they think that moral requirements generate overriding reasons to abide by them, others, like myself, may be driven to accept moral rationalism because they think that morality is limited in what it can require of us - that morality can require us to do only that which we have decisive reason to do, all things considered. The thought would be that although moral requirements do not generate overriding reasons to abide by them, moral rationalism is, nevertheless, true, for non-moral reasons 
serve to constrain what morality can require of us in that they sometimes successfully counter our moral reasons, preventing them from generating moral requirements.

Schematically, then, Portmore argues like this. One, reasons determine moral requirements; two, these reasons are moral and non-moral, consequentialist as well as non-consequentialist; three, the morality so produced is nonetheless a consequentialist morality. This reasoning indeed preserves moral rationalism since, as Portmore above explains, nothing will be allowed to come out as a moral requirement that doesn't have the support of reasons.

Of course, the reasoning is eminently questionable. ${ }^{42}$ I already mentioned that step one offers only one picture of morality and rationality and I added that Portmore argues for step two. It is an even less straightforward matter, and takes Portmore the rest of his book to argue for, that the resulting morality will be consequentialist. ${ }^{43}$ Finally, and perhaps most importantly, Portmore's consequentialism is not the consequentialism of this chapter. He takes consequentialism of that kind to be defeated by the demandingness objection. In other words, what Portmore does is to restructure consequentialism and thereby deny premise (1) of the demandingness objection. Hence, even if his argument succeeds, there will still be the question whether his consequentialism is indeed one we want to accept. Needless to say, just as with the other two responses, there is no space here to take up any of these matters. I believe Portmore's theory is promising and deserves detailed discussion, but this cannot be conducted in this chapter. ${ }^{44}$

\section{Summary and Concluding Remarks}

In this chapter I set out to do three things. (1) I wanted to clarify what the demandingness objection is about. (2) I wanted to explain why the objection targets only consequentialism. (3) I wanted to present responses that are (relatively) underexplored in the literature. I hope to have accomplished the first two tasks and at least partially carried out the third. I do not claim to have not left questions open; in fact, at least in the case of potential responses, my intention was to raise questions. To answer those questions, however, is a task left for another occasion.

\section{Notes}

1 Those who want to read about consequentialism in more detail can turn to SinnottArmstrong (2014). Mulgan (2007) and Bykvist (2010) also provide very good introductory discussions and of course most introductory ethics texts will have a detailed discussion of the theory. 
2 Henceforth: "consequentialism," unless qualifier needed. In the rest of this chapter I will use the terms "consequentialism" and "utilitarianism" synonymously: the objections to utilitarianism that I will consider are also objections to consequentialism and vice versa.

3 The first comes from Mulgan (2007), page 95, the second from Bykvist (2010), page 98.

4 See Cullity (2004) and (2009) for introducing and making substantial use of these iterated demands.

5 Precision at this point would require clarification of the notion of "demand," but I cannot do this in the present chapter. I wrote more about this in Tanyi (2012). One point deserves short notice, though. Some philosophers argue that in addition to costs one should also consider the factor Scheffler (1992: 98) calls confinement. In his formulation a moral theory is confining to the extent the constraints it involves narrow the range of morally acceptable courses of action open to the agent. It is, however, questionable whether confinement indeed constitutes an independent factor. Murphy (2000: 29-30), for instance, argues that a large part of confinement can be explained as losses that the agent suffers in her well-being when obeying with moral dictates, and this is just the traditional understanding of a moral demand.

6 Unfortunately, it is easy to cite statistics for this claim. Any report by the World Health Organization (WHO), the World Bank, the United Nations Children's Fund (UNICEF), the United Nations Development Programme (UNDP), and so on paints the same dire picture, certainly of the global situation, but also, in most cases, of domestic circumstances. See Miklós (2013: 2-3) for more data and references.

7 See also Williams (1973b) and Stocker (1976) for a very similar objection. It is clear that the integrity objection is closely allied to Williams' thinking about internal reasons in Williams (1981a). See Hurley (2009: Chapter 4) who works out this connection in detail.

8 What happens if the agent has no lower-order projects? In this case, no alienation and integrity charge follows. However, this is certainly an extreme case, the truest form of what Wolf (1982) calls a moral saint, and comes with other problems, as Wolf demonstrates. Moreover, it is also clear that not everyone can be (even if, contra Wolf, should be) a moral saint. Being a higher-order project, utilitarianism needs lower-order projects, that is, it needs people who have those projects and are thus not saints themselves.

9 Hence Williams' (1981b) charge that utilitarianism requires the agent to have "one thought too many" when doing the morally right thing. Jim's motivating thought in helping the Indians wouldn't merely be, as it should be, that they are in trouble and need help, but also that this action is permitted (or required) by morality. See also Smith's (1995) related fetishism charge for further discussion.

10 There are some loose ends here, though. In particular, it is a question how important the utilitarian project must be as compared to the other, lower- and higherorder projects of the agent. Hurley (2009: Chapter 4) argues that it must be the agent's most important, ultimate project that subsumes all other lower-order projects. Now, the integrity objection is about how utilitarianism forces the agent to look at his or her central commitments in life and as such, it seems to hold even if the utilitarian higher-order project is not a project of ultimate importance. However, if it is not such an ultimate project, it means that on certain occasions at least, the agent can experience his or her lower-order projects in the proper (i.e. non-alienating) way and this certainly tones down (if not eliminates) the force of Williams' objection. 
11 For the relevant consequentialist responses on doing versus allowing, see HowardSnyder (2011); on the separateness of persons, see Parfit (1984), Brink (1997); on issues of integrity, see Railton (1984) and Scheffler (1992).

12 To give an example, in Jim and the Indians, there is the cost that Jim is required to bear if he decides to shoot the one chosen Indian: namely, that he becomes a killer. At the same time, there is also the cost that will befall upon all the Indians who will be shot by Pedro if Jim decides not to shoot the one chosen Indian and thereby prevent Pedro from killing every Indian.

13 The first option in the disjunctive statement keeps the demandingness objection, but extends it to other theories. However, the second option is in effect a response to the objection, often called the "companions in guilt" strategy. See Ashford (2003) for employing this line of reasoning on the ground that Scanlon's contractualism is also excessively demanding. See Mulgan (2007) and Bykvist (2010) for a general discussion of this strategy.

14 Unless it can be proven that no such intuition really exists or for some reason it is not to be relied upon. Such result could follow if, as Parfit (2011) claims, all the main moral theories (when properly understood) converge. But of course this is a big "if" and many do not seem to agree with Parfit's conclusion in his monumental work.

15 See Bykvist (2010: 105) and Portmore (2011: 134) for two attempts to resolve the paradox but not in the "proper" way, that is, without putting an end to the demandingness problem.

16 I understand "decisive reason" and "most reason" to mean the same. There are some complications here, which I am disregarding in this chapter. In particular, the two notions come apart if reasons can behave "unusually," for example, if they can silence or bracket each other. For more on this kind of behavior of reasons, see Tanyi (2013).

17 The labels I use for these response strategies come from Mulgan (2001).

18 For a thorough discussion and criticism of the first, empirical strategy, see Mulgan (2001) and Bykvist (2010). The second approach, the restructuring strategy has given rise to such positions as sub-maximizing consequentialism (Slote 1984; for criticism, see Pettit 1984 and Bradley 2006), two-level consequentialism (Hare 1981; and in general the distinction between decision procedure and criterion of rightness in Railton 1984; for criticism, see McNaughton 1988), rule-consequentialism (most recently Hooker 2000; for criticism, see Mulgan 2001), limited consequentialism (Scheffler 1992, 1994; for criticism, see Kagan 1984), cooperative consequentialism (Murphy 2000; for criticism, see Mulgan 2001), and combined consequentialism (Mulgan 2001).

19 This is anyway what they should claim. Often, however, as Portmore (2011: 26) points out, the extremist claim seems to be that consequentialism is indeed too demanding in this sense, but this is not objectionable. In other words, the strategy would then accept premise (2), but deny premise (4). But this is certainly no way to proceed since consequentialists simply cannot grant to their opponents the truth of the claim that their theory makes demands that are not morally right. This would obviously be self-defeating for the theory.

20 See Kagan (1989); Singer (1972); Tännsjö (2002); Unger (1996); Sobel (2007); for critical discussion of this approach, see Cullity (1994) and Mulgan (2001, 2007). The intuition extremists focus on can be just those particular intuitions that certain counterexamples are meant to evoke against their theory (such as, e.g., in Your Money and Charity); or they can focus on moral intuitions in general. The latter way of arguing gave rise to a separate debate about the use of intuitions in moral theory. See Singer (2005) versus Sandberg and Juth (2011).

21 In this section, unless otherwise stated, all page references in brackets will be to this book. 
22 That is, as Peterson elsewhere explains, "something counts as an aspect if and only the deontic status of an act varies if we hold constant everything but the putative aspect in question" (15).

23 The clause "can be characterized" in the definition of one-dimensional consequentialism is important because it makes the set of one-dimensional theories less restricted. For all it requires is that we find a moral aspect that makes it possible to characterize an act's deontic status as a function of that one aspect; this does not rule out that another characterization exists that employs several moral aspects.

24 He brings geometry as an analogous case: "The area of the circle depends on only one aspect (its radius) whereas the area of the triangle depends on two aspects (its base and height). All three aspects are elements of the same dimension (length). This is not always the case, however, as can be seen by considering an analogy with physics: mass and time are different aspects, but they are also elements of different dimensions" (4).

25 Peterson defines incomparability as the claim that "for some consequences, no pairwise evaluative comparisons can be made." As for the other notion, his definition is that "two elements are on a par if and only if they are comparable, although it is false that one is at least as good as the other" (9).

26 I do this in an unpublished paper coauthored with Vuko Andric. We focus on the relation between $\mathrm{C} 1$ and $\mathrm{C} 3$ and the argument for $\mathrm{C} 3$.

27 Or least wrong: Since we are dealing with all-things-considered rightness and wrongness, the act that is most right is also the least wrong (the two degrees must add up to 1 ).

28 Another problem is that it is not clear that what Peterson is talking about in discussing the case is indeed degrees of rightness/wrongness and not what he calls moral strength (see his Chapter 2.4 on this distinction). Roughly, how much we donate appears to be about how much moral value we produce or fail to produce and this is strength, not degree (that is given by the important moral value of helping/saving lives, which is the same in all instances), according to Peterson (cf. 2013: 93, 117).

29 Satisficing consequentialism is the view that the right thing to do is what is good enough, for example, produces enough utility. See Slote (1984) for the original formulation and Bradley (2006) for criticism. Sufficientarianism is a view about how to distribute goods fairly and holds that the right distribution is the one in which no individual is allowed to fall below a certain threshold. See Crisp (2003) for a recent statement and Temkin (2003) for criticism.

30 Agent-relative values are values that make essential reference to the agent who has the value: the value of special relationships (family, love), for instance, is agent-relative since it is essential to mention whose relations we are talking about in order to understand the goodness of these relationships. On the agent-relative versus agentneutral distinction in more detail, see Ridge (2011). Consequentialism traditionally operates with agent-neutral values only: it does not matter, for example, whose pleasure or pain we are talking about-the badness of these states can be understood without reference to the agent who has them. However, some consequentialists recently attempted to broaden consequentialism to accommodate agent-relative values as well. On an insightful critique of what is often called evaluator-relative consequentialism, see Schroeder (2007). A person-relative dimension of value, I take it, could be Peterson's versions of this idea: it would incorporate agent-relativity into the dimension of person (and thus well-being).

31 For a good discussion of the ideal versus non-ideal theory distinction, see Simmons (2010).

32 Although there are other objections to dualism in the literature (I have in mind Cohen 1992, 1997, 2000 and Nagel 1991), these are discussed and responded to by 
others (such as Scheffler 2005, 2006). The chapter by Andres Moles in this volume also has a good discussion of several of the issues these authors raise.

33 Again, a good discussion of the upcoming issues can be found in the chapter by Andres Moles in this volume.

34 Some, like Nagel (2005), seem to hold that a non-relational theory must be monist, but I fail to see the connection. The relational/non-relational distinction concerns the grounds of justice (with consequences for its scope), whereas the monism/dualism distinction is about the site of justice. Although both invoke institutions, they do so in an entirely different role.

35 For an early representative see Pogge (1994); for a more recent contributions, see Moellendorf (2011).

36 See, for example, Nussbaum (2007) for a long list of the relevant institutions and schemes.

37 Hurley (2009: Chapter 2) presents this problem as a "troubling normative triad" for consequentialism. The elements of the triad are the consequentialist moral standard (CMS), the existence of non-impersonal reasons (NIR), and the rational authority of moral standards (RAMS). The point is the same as in my presentation: the elements of the triad cannot be fitted together into one coherent, defensible whole.

38 There are also those responses that reject the argument by questioning what it assumes. Scalar-consequentialists claim that consequentialism makes no demands on us, although it does give us reasons to act. See Norcross (2006); for a response, see McElwee (2011). What we might call normative relativism argues that every reason is relative to a point of view, hence there is common platform on which they can compete with each other. See Kagan (1989) and Copp (1997); for a criticism, see McLeod (2001).

39 Evaluator-relative consequentialism, mentioned in footnote 29, is one attempt, Cummiskey (1996)'s Kantian consequentialism is another. For a critical discussion of the latter see Hurley (2009: Chapter 6.2). But we should note that these theories only deal with a subset of all the "missing" reasons and hence cannot be taken as providing a complete response, even if they do not fail otherwise.

40 With Martin Bruder, I have been carrying out research along these lines with promising results that show that the majority of people regard consequentialist reasons as overriding other considerations See, for example, Bruder and Tanyi (2014).

41 Sobel (2007: 14-15) appears to be in agreement with this. Portmore (2011) disagrees but, as we shall see, he doesn't share this picture of morality and rationality. He also provides an intricate argument for moral rationalism that he defends in detail. I say more about his argument for moral rationalism in Tanyi (2012), but no doubt, more critical discussion would be needed.

42 Hurley (1999: 122), for instance, endorses Portmore's general picture about reasons and morality - he calls it the moral authority of rational standards (MARS) - but thinks that it leads nowhere near to consequentialism.

43 In particular, Portmore (2011: Chapter 3) argues for a teleological conception of reasons that he claims to be embedded in consequentialism.

44 For some initial attempts, see Hurley (2014), Archer (2014), and Gert (2014).

\section{References}

Archer, A. (2014). “Moral Rationalism without Overridingness.” Ratio 27: 100-114.

Ashford, E. (2003). “The Demandingness of Scanlon's Contractualism.” Ethics 113: 273-304.

Bradley, B. (2006). “Against Satisficing Consequentialism." Utilitas 18: 97-108. 
Brink, D. O. (1997). "Kantian Rationalism: Inescapability, Authority, and Supremacy." In G. Cullity and B. Gaut (eds), Ethics and Practical Reason, pp. 255-91. New York: Oxford University Press.

Bruder, M. and Tanyi, A. (2014). "Overdemanding Consequentialism? An Experimental Approach." Utilitas 26 (3): 250-75.

Bykvist, K. (2010). Understanding Utilitarianism. London: Continuum.

Carter, A. (2009). "Is Utilitarian Morality Necessarily too Demanding?" In T. Chappell (ed.), The Problem of Moral Demandingness: New Philosophical Essays, pp. 163-185. London: Palgrave MacMillan.

Cohen, G. A. (1992). "Incentives, Inequality, and Community.” In G. B. Peterson (ed.), The Tanner Lectures on Human Values, Vol. 13. Salt Lake City: University of Utah Press.

Cohen, G. A. (1997). "Where the Action Is: On the Site of Distributive Justice." Philosophy and Public Affairs 26 (1): 3-30.

Cohen, G. A. (2000). If You're an Egalitarian, How Come You're So Rich?. Oxford: Oxford University Press.

Copp, D. (1997). "The Ring of Gyges: Overridingness and the Unity of Reason." Social Philosophy and Policy 14: 86-106.

Crisp, R. (2003). "Equality, Priority, and Compassion." Ethics 113: 745-63.

Cullity, G. (1994). "International Aid and the Scope of Kindness." Ethics 105: 99-127.

Cullity, G. (2004). The Moral Demands of Affluence. Oxford: Clarendon Press.

Cullity, G. (2009). "Demandingness and Arguments from Presupposition." In T. Chappell (ed.), The Problem of Moral Demandingness: New Philosophical Essays, pp. 8-35. London: Palgrave MacMillan.

Cummiskey, D. (1996). Kantian Consequentialism. Oxford: Oxford University Press.

Gert, J. (2014). “Perform a Justified Option," Utilitas 26 (2): 206-17.

Hare, R. M. (1981). Moral Thinking. Oxford: Clarendon Press.

Hooker, B. (2000). Ideal Code, Real World: A Rule Consequentialist Theory of Morality. Oxford: Clarendon Press.

Hooker, B. (2009). “The Demandingness Objection.” In T. Chappell (ed.), The Problem of Moral Demandingness: New Philosophical Essays, pp. 148-63. London: Palgrave MacMillan..

Howard-Snyder, F. (2011). “Doing vs. Allowing Harm." The Stanford Encyclopedia of Philosophy (Winter 2011 Edition), Edward N. Zalta (ed.), <http://plato.stanford. edu/archives/win2011/entries/doing-allowing/>.

Hurley, P. (2009). Beyond Consequentialism. New York: Oxford University Press.

Hurley,P.(2014). "CommentsonDouglasPortmore's CommonsenseConsequentialism." Philosophy and Phenomenological Research 88 (1): 225-32.

Kagan, S. (1984). "Does Consequentialism Demand Too Much?" Philosophy and Public Affairs 13 (3): 239-54.

Kagan, S. (1989). The Limits of Morality. Oxford: Clarendon Press.

Mackie, J. L. (1977). Ethics: Inventing Right and Wrong. London: Penguin.

McElwee, B. (2011). "Impartial Reasons, Moral Demands." Ethical Theory and Moral Practice 14: 457-66.

McLeod, O. (2001). “Just Plain ‘Ought.'” Journal of Ethics 5: 269-91.

McNaughton, D. (1988). Moral Vision. London: Wiley-Blackwell. 
The Bloomsbury Companion to Analytic Philosophy

Miklós, A. (2013). Institutions in Global Distributive Justice. Edinburgh: Edinburgh University Press.

Miklósi, Z. (2008). “Compliance with Just Institutions." Social Theory and Practice 34 (2): 183-207.

Moellendorf, D. (2011). “Cosmopolitanism and Compatriot Duties.” The Monist 94 (4): 535-54.

Mulgan, T. (2001). The Demands of Consequentialism. Oxford: Clarendon Press.

Mulgan, T. (2007). Understanding Utilitarianism. Stocksfield: Acumen.

Murphy, L. D. (1998). "Institutions and the Demands of Justice." Philosophy and Public Affairs 27 (4): 251-91.

Murphy, L. D. (2000). Moral Demands in Nonideal Theory. Oxford: Oxford University Press.

Nagel, T. (1991). Equality and Partiality. New York: Oxford University Press

Nagel, T. (2005). "The Problem of Global Justice.", Philosophy and Public Affairs 33 (2): 113-47.

Norcross, A. (2006). "Reasons without Demands: Rethinking Rightness." In James Dreier (ed.), Contemporary Debates in Moral Theory, pp. 38-53. Oxford: Blackwell.

Nussbaum, M. (2007). Frontiers of Justice. Cambridge, MA: Harvard University Press.

Parfit, D. (1984). Reasons and Persons. Oxford: Oxford University Press.

Parfit, D. (1984). On What Matters. Oxford: Oxford University Press.

Peterson, M. (2013). The Dimensions of Consequentialism. Cambridge: Cambridge University Press.

Pettit, P. (1984). "Satisficing Consequentialism." Proceedings of the Aristotelian Society, Supplementary Volume 58: 165-76.

Pogge, T. (1994). "An Egalitarian Law of Peoples." Philosophy and Public Affairs 23 (3): 195-224.

Portmore, D. W. (2011). Commonsense Consequentialism: Wherein Morality Meets Rationality. Oxford: Oxford University Press.

Railton, P. (1984). "Alienation, Consequentialism, and the Demands of Morality." Philosophy and Public Affairs 13: 134-71.

Rawls, J. (1971). A Theory of Justice. Cambridge, MA: Harvard University Press.

Ridge, M. (2011). "Reasons for Action: Agent-Neutral vs. Agent-Relative." The Stanford Encyclopedia of Philosophy (Winter 2011 Edition), Edward N. Zalta (ed.), $<$ http://plato.stanford.edu/archives/win2011/entries/reasons-agent/>.

Sandberg, J., and Juth, N. (2011). "Ethics and Intuitions: A Reply to Singer." Journal of Ethics, 15 (3): 209-26.

Scheffler, S. (2005). "The Division of Moral Labour: Egalitarian Liberalism as Moral Pluralism." Proceedings of the Aristotelian Society, Supplementary Volume 79: 229-53.

Scheffler, S. (2006). "Is the Basic Structure Basic?" In C. Sypnowich (ed.), The Egalitarian Conscience: Essays in Honour of G.A. Cohen, pp. 102-29. Oxford: Oxford University Press.

Scheffler, S. (1992). Human Morality. New York: Oxford University Press.

Scheffler, S. (1994). The Rejection of Consequentialism. Oxford: Clarendon Press, Revised edition. 
Schroeder, M. (2007). “Teleology, Agent-Relative Value, and 'Good'*." Ethics 117: 265-95.

Sidgwick, H. (1907). The Methods of Ethics. Cambridge: Cambridge University Press, 7th edition.

Simmons, A. J. (2010). "Ideal and Nonideal Theory." Philosophy and Public Affairs 38 (1): 5-36.

Singer, P. (1972). "Famine, Affluence, and Morality." Philosophy and Public Affairs 1 (3): 229-43.

Singer, P. (2005). “Ethics and Intuitions." Journal of Ethics 9: 331-52.

Sinnott-Armstrong, W. (2014). "Consequentialism." The Stanford Encyclopedia of Philosophy (Spring 2014 Edition), Edward N. Zalta (ed.), <http://plato.stanford. edu/archives/spr2014/entries/consequentialism/>.

Slote, M. (1984). "Satisficing Consequentialism." Proceedings of the Aristotelian Society 58: 139-63.

Smith, M. (1995). The Moral Problem. New York: Oxford University Press.

Sobel, D. (2007). "The Impotence of the Demandingness Objection." Philosophers' Imprint 7: 1-17.

Stocker, M. (1976). "The Schizophrenia of Modern Ethical Theories." Journal of Philosophy 73: 453-66.

Stroud, S. (1998). “Overridingness and Moral Theory.” Pacific Philosophical Quarterly 79: $170-89$.

Tännsjö, T. (2002). Understanding Ethics: An Introduction to Moral Theory. Edinburgh: Edinburgh University Press.

Tännsjö, T. (2008). Global Democracy: The Case for a World Government. Edinburgh: Edinburgh University Press.

Tanyi, A. (2012). "The Case for Authority." In S. Schleidgen (ed.), Should We Always Act Morally? Essays on Overridingness, pp. 159-89. Marburg: Tectum.

Tanyi, A. (2013). “Silencing Desires?” Philosophia 41 (3): 887-903.

Temkin, L. (2003). “Egalitarianism Defended.” Ethics 113: 764-82.

Unger, P. (1996). Living High and Letting Die. New York: Oxford University Press.

Williams, B. (1973a). “A Critique of Utilitarianism." In J. J. Smart and B. Williams (eds), Utilitarianism: For and Against, pp. 77-151. Cambridge: Cambridge University Press.

Williams, B. (1973b). "Morality and the Emotions." In B. Williams (ed.), Problems of the Self, pp. 207-30. Cambridge: Cambridge University Press.

Williams, B. (1981a). "Persons, Character and Morality." In B. Williams (ed.), Moral Luck, pp. 1-19. Cambridge: Cambridge University Press.

Williams, B. (1981b). "Internal and External Reasons." In B. Williams (ed.), Moral Luck, pp. 101-14. Cambridge: Cambridge University Press.

Wolf, S. (1982). "Moral Saints." Journal of Philosophy 79: 419-39. 